\title{
EFFECT OF SELECTED COMPONENTS ON COMBUSTION OF METHANE
}

\author{
CHRÍBIK Andrej ${ }^{1 *}$, MINÁRIK Matej ${ }^{1}$, POLÓNI Marián $^{1}$ \\ ${ }^{1}$ Slovak University of Technology in Bratislava, Faculty of Mechanical Engineering, Institute of transport \\ technology and designing, Nám. Slobody 17,812 31 Bratislava, Slovakia, e-mail:andrej.chribik@stuba.sk
}

\begin{abstract}
Article discusses the effect of various gases on the combustion of methane in LGW 702 combustion engine intended for use in cogeneration unit. The measured results were evaluated for internal, performance and economic parameters of the combustion engine the ideal operating parameters can be set. The aim of the study was to assess the effect of combustible carbon monoxide and carbon dioxide and nitrogen on the parameters.
\end{abstract}

KEYWORDS: methane, carbon dioxide, carbon monoxide, nitrogen, spark ignition engine

\section{Introduction}

As the whole world tries to lower the emissions of greenhouse gases the effective use of other than conventional energy sources are gaining foothold. Municipal solid waste, its gasification and following energy production is considered such source of energy. Nonseparable waste can be turned to syngas through various gasification processes. The most common processes are direct and indirect gasification and pyrolysis. [1,2] By employing such treatment gas, tars/oils and char are created. Controlling the amount of tars and particulate matter are of highest priority in combustion engines. This means, that the produced syngas needs to be cleaned prior to combustion. If left untreated, injector nozzles may become blocked by particulate matter. Therefore, the amount of PM shouldn't exceed $50 \mathrm{mg} / \mathrm{Nm} 3$ and size of $10 \mu \mathrm{m}$. Below the $100^{\circ} \mathrm{C}$ most of the tars are condensed, therefore the hot gas should be filtered for tars. If the excess of tars are being present in the gas powering the engine, the pipes of the engine, as well as valves may become clogged $[3,4,5,6]$.

The cleaned gas, which is the main interest of this paper, consists mainly of hydrogen $\left(\mathrm{H}_{2}\right)$, carbon monoxide $(\mathrm{CO})$, carbon dioxide $\left(\mathrm{CO}_{2}\right)$, nitrogen $\left(\mathrm{N}_{2}\right)$ and methane $\left(\mathrm{CH}_{4}\right)$. The inert components tend to reduce maximum in-cylinder pressure as more of the space inside the cylinder is occupied by the non-combustible gas, therefore, overall stress on crank mechanism is reduced. [7] The content of each component in the gas is dependant mainly on the type of feedstock and type of gasifying process used. As the non-separable municipal waste is continuously fed to the reactor, the produced gas composition is changing with time due to nonuniformity of the waste. By finding the optimal ignition angle for various mixtures, it is possible to understand the influence of various gas components on the combustion. Such syngases can be also be used in dual-fuel compression ignition engines where the lean mixture is ignited by various types of bio-oils or oil from pyrolysis $[8,9]$.

This article represents the partial study of the influence of inert gases $\left(\mathrm{CO}_{2}\right.$ and $\left.\mathrm{N}_{2}\right)$ and carbon monoxide on combustion of methane and natural gas. The natural gas at the time of measurement consisted of $98 \%$ of methane, therefore it was assumed, that the results should be consistent with those of pure methane. The in-cylinder pressure used to evaluate the start of 
combustion (SOC) and end of combustion (EOC) was measured with Kistler 6117 BDC15 spark plug coupled with Kistler 2614A rotational encoder used to determine the exact position of crankshaft. Spark plugs were connected to charge-amplifier coupled with A/D converter. The engine used in the experiment was modified Lombardini LGW 702, twin cylinder, watercooled, four-stroke engine. The original pistons were machined to reach compression ratio of 12.5:1 from the former ratio of 22.8. The fresh charger was prepared in mixer with a difusser. The whole measuring stand can be found on the following figure (Fig. 1).

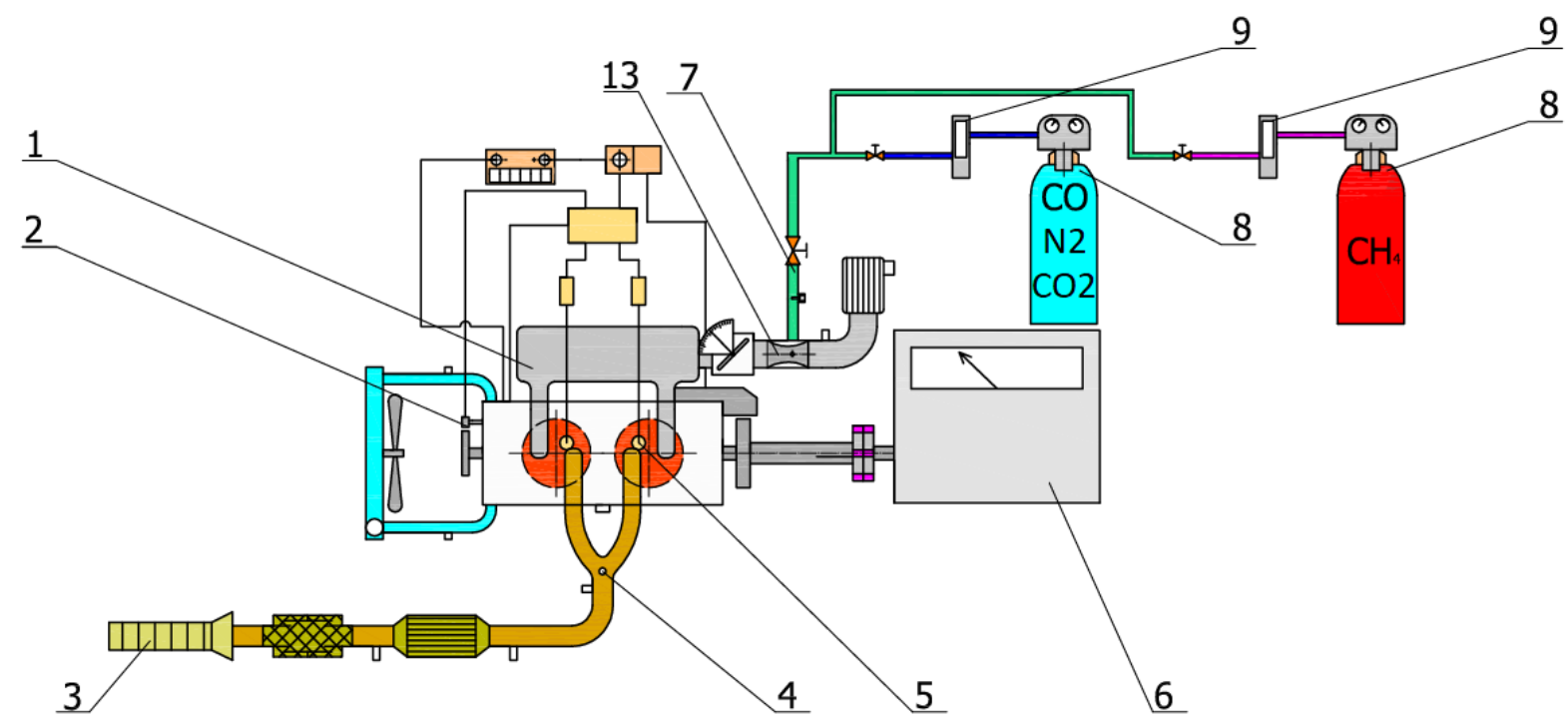

Fig. 1 Basic scheme of measuring for LGW 702 engine (1 - intake manifold, 2 - Kistler rotational encoder, 3 - Exhaust tip, 4 - Exhaust temperature sensor, 5 - Kistler 6117 measuring spark plug, 6 - AVL dynamometer, 7 - Stepper motor richness regulation, 8 Pressure bottles $\left(\mathrm{CH}_{4}\right.$ and $\left.\mathrm{CO} / \mathrm{CO}_{2} / \mathrm{N}_{2}\right), 9-$ Gas mass flow meter

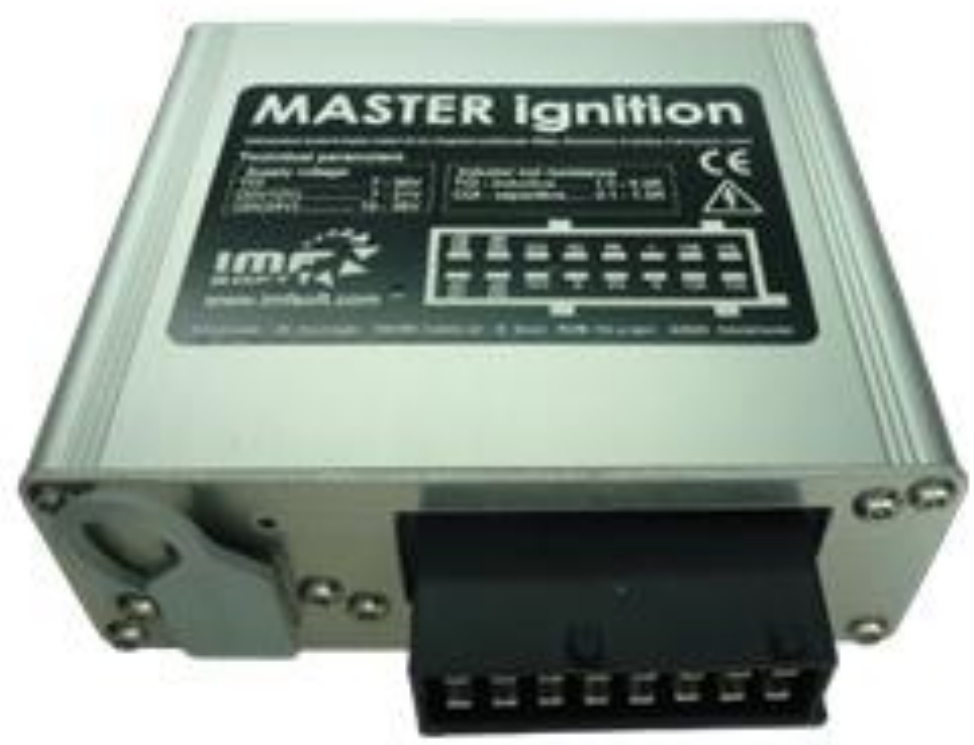

Fig. 2 Engine ECU used in experiment 
The gas was supplied from pressure bottles and entered the intake system through a gas diffuser. The regulation of the stoichiometry was carried out by a stepper motor controlled by a feedback controller. As the narrow-band lambda controllers only sense if the mixture is rich or lean, secondary wide band lambda controller was also employed to monitor the operation of the feedback system. Optimization of ignition timing was achieved by an IMF Soft Master ignition control unit. The timing signal was measured on camshaft fitted with 5 sensing elements. As the control unit possess direct TCI ignition output, a coil on plug system was chosen to deliver a spark energy of up to $65 \mathrm{~mJ}$ through a BOSCH P-65T coil-on-plug ignition coils. The maximum of $65 \mathrm{~mJ}$ energy was chosen based on a fact, that high content of inert gases tends to increase the minimum ignition energy. This ensures a successful ignition of all mixtures.

As carbon monoxide is combustible gas, 7 different measurements were done. First, clean $\mathrm{CH}_{4}$ was evaluated. In consecutive runs, the content of $\mathrm{CO}$ was increased up to $100 \% \mathrm{CO}$. The effect of inert gases was measured on four different mixtures. The methane was diluted with $25 \%$ and $50 \%$ of inert gas for both, $\mathrm{CO}_{2}$ and $\mathrm{N}_{2}$. The chemical and physical properties of the mixtures can be found in the following table (Table 1).

Table 1 Physical and chemical parameters of mixtures used in experiment

\begin{tabular}{|c|c|c|c|c|c|c|c|c|c|c|c|c|}
\hline \multicolumn{2}{|c|}{ Mixture } & \multicolumn{7}{|c|}{$\mathrm{CH} 4 / \mathrm{CO}$} & \multicolumn{2}{|c|}{ NG/CO2 } & \multicolumn{2}{|c|}{ NG/N2 } \\
\hline $\begin{array}{l}\text { NG/CH4 } \\
\text { content }\end{array}$ & [\%vol] & 100 & 63.4 & 29.4 & 13.9 & 4.9 & 2.2 & 0 & 75 & 50 & 75 & 50 \\
\hline $\begin{array}{c}\mathrm{CO} / \mathrm{CO}_{2} / \mathrm{N}_{2} \\
\text { content }\end{array}$ & [\%vol] & 0 & 36.6 & 70.6 & 86.1 & 95.1 & 97.8 & 100 & 25 & 50 & 25 & 50 \\
\hline Density & {$\left[\mathrm{kg} \cdot \mathrm{m}^{-3}\right]$} & 0.72 & 0.881 & 1.049 & 1.09 & 1.134 & 1.15 & 1.16 & 1.216 & 1.509 & 0.8511 & 0.984 \\
\hline $\begin{array}{c}\text { Molar } \\
\text { mass }\end{array}$ & {$\left[\mathrm{kg} \cdot \mathrm{kmol}^{-1}\right]$} & 16 & 20.39 & 24.47 & 26.33 & 27.41 & 27.73 & 28 & 23 & 30 & 19 & 22 \\
\hline $\begin{array}{l}\text { Lower } \\
\text { heating } \\
\text { value }\end{array}$ & {$\left[\mathrm{MJ} . \mathrm{kg}^{-1}\right]$} & 50.03 & 29.96 & 17.78 & 13.47 & 11.24 & 10.61 & 10.11 & 26.11 & 13.34 & 31.601 & 17.94 \\
\hline AFR ratio & {$[-]$} & 17.24 & 9.81 & 5.30 & 3.71 & 2.88 & 2.65 & 2.46 & 8.99 & 4.598 & 10.889 & 6.269 \\
\hline $\begin{array}{l}\text { Mixture } \\
\text { mass } \\
\text { heating } \\
\text { value }\end{array}$ & {$\left[\mathrm{MJ} . \mathrm{kg}^{-1}\right]$} & 2.74 & 2.77 & 2.82 & 2.86 & 2.90 & 2.91 & 2.92 & 2.612 & 2.384 & 2.658 & 2.503 \\
\hline $\begin{array}{c}\text { Mixture } \\
\text { volume } \\
\text { heating } \\
\text { value }\end{array}$ & {$\left[\mathrm{MJ} . \mathrm{m}^{-3}\right]$} & 3.19 & 3.14 & 3.21 & 3.31 & 3.40 & 3.44 & 3.48 & || 2.971 & 2.748 & 3.00 & 2.786 \\
\hline
\end{tabular}

\section{Experimental}

Optimal ignition angle was controlled manually through a PC software supplied with the ECU. The measurements conditions were $1500 \mathrm{~min}^{-1}$, full engine load and stoichiometric mixture. All measurements were performed at full load. The results were measured and compared to reference fuel $\left(\mathrm{CH}_{4}\right)$. In case of all fuels and mixtures, pressure traces of only the optimal ignition angle of methane $\left(24.4^{\circ} \mathrm{CA}\right.$ BTDC) were evaluated.

The duration of combustion (10-90MFB) for methane lasted $24.4^{\circ} \mathrm{CA}$. Pure carbon monoxide had a combustion duration of $30.7^{\circ} \mathrm{CA}$. The dependence of combustion period on content of the species is not linear. By mixing $5 \%$ to around $15 \%$ vol of $\mathrm{CH}_{4}$ with $\mathrm{CO}$ the main combustion period was shortened to $17^{\circ} \mathrm{CA}$. This is caused by the introduction of hydrogen containing species which 
enhance the oxidation of $\mathrm{CO}$. The $\mathrm{HO}_{2}, \mathrm{H}$ and $\mathrm{OH}$ all speed increases the oxidation rates of $\mathrm{CO}$. The ignition delay for such mixture is also the shortest, lasting only $15^{\circ} \mathrm{CA}$. Value for methane is $22^{\circ} \mathrm{CA}$ and $18^{\circ} \mathrm{CA}$ for $\mathrm{CO}$.

The maximum engine in-cylinder pressure reached lowest value of 4.7 MPa while running on carbon monoxide. By increasing the content of $\mathrm{CH}_{4}$, the pressure steadily increased and reached a maximum value of $7.1 \mathrm{MPa}$ at $13.9 \%$ of $\mathrm{CH}_{4}$. By further increasing the $\mathrm{CH}_{4}$ content the maximum in cylinder pressure decreased. The maximum pressure for pure methane was $5.6 \mathrm{MPa}$. The point of maximum pressure was between $374.4^{\circ}$ and $369.1^{\circ} \mathrm{CA}$ for constant ignition angle of $24^{\circ} \mathrm{CA}$ as can be seen from Fig. 4.

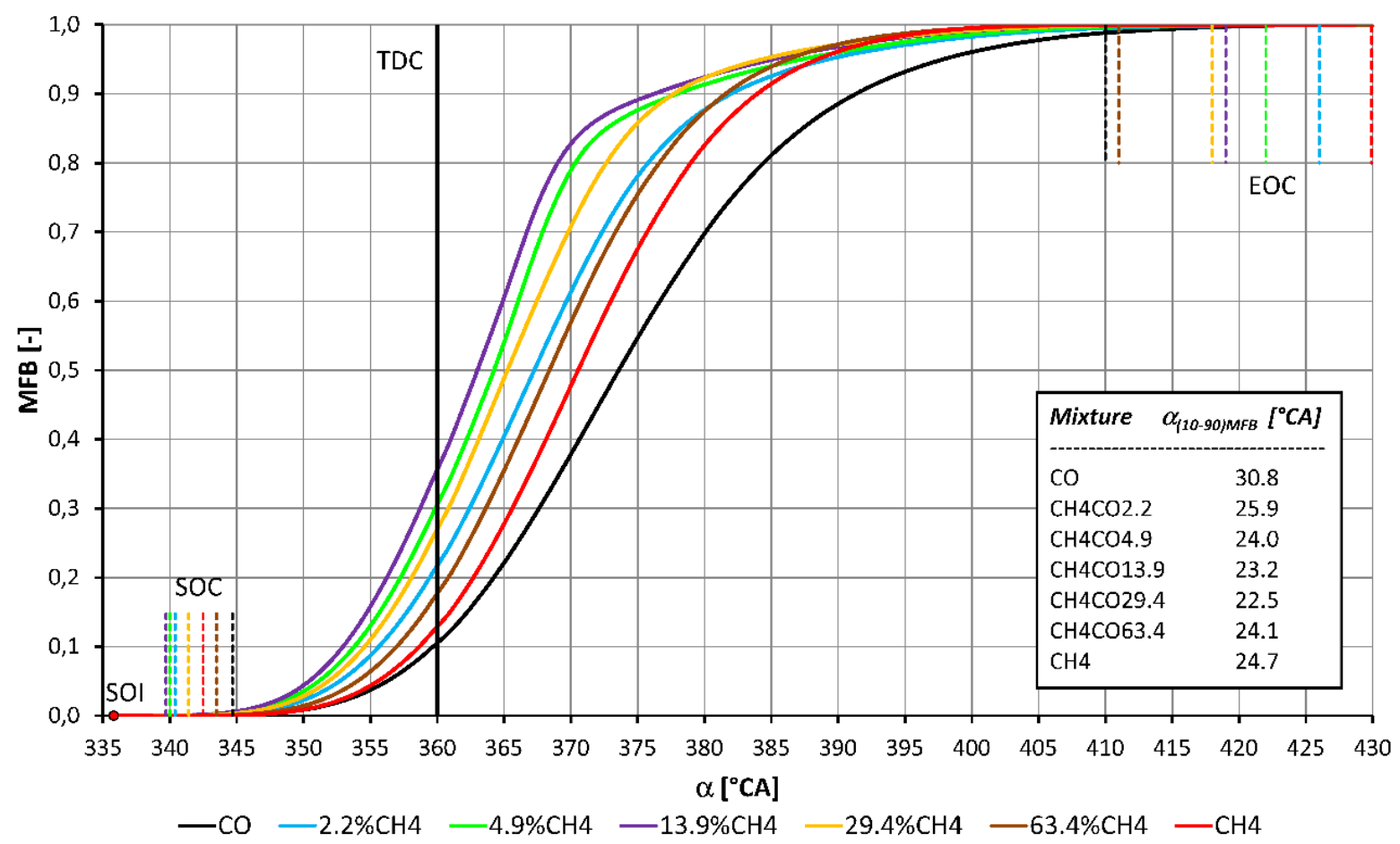

Fig. 3 Course of in-cylinder heat release for various $\mathrm{CO}$ and $\mathrm{CH} 4$ mixtures 


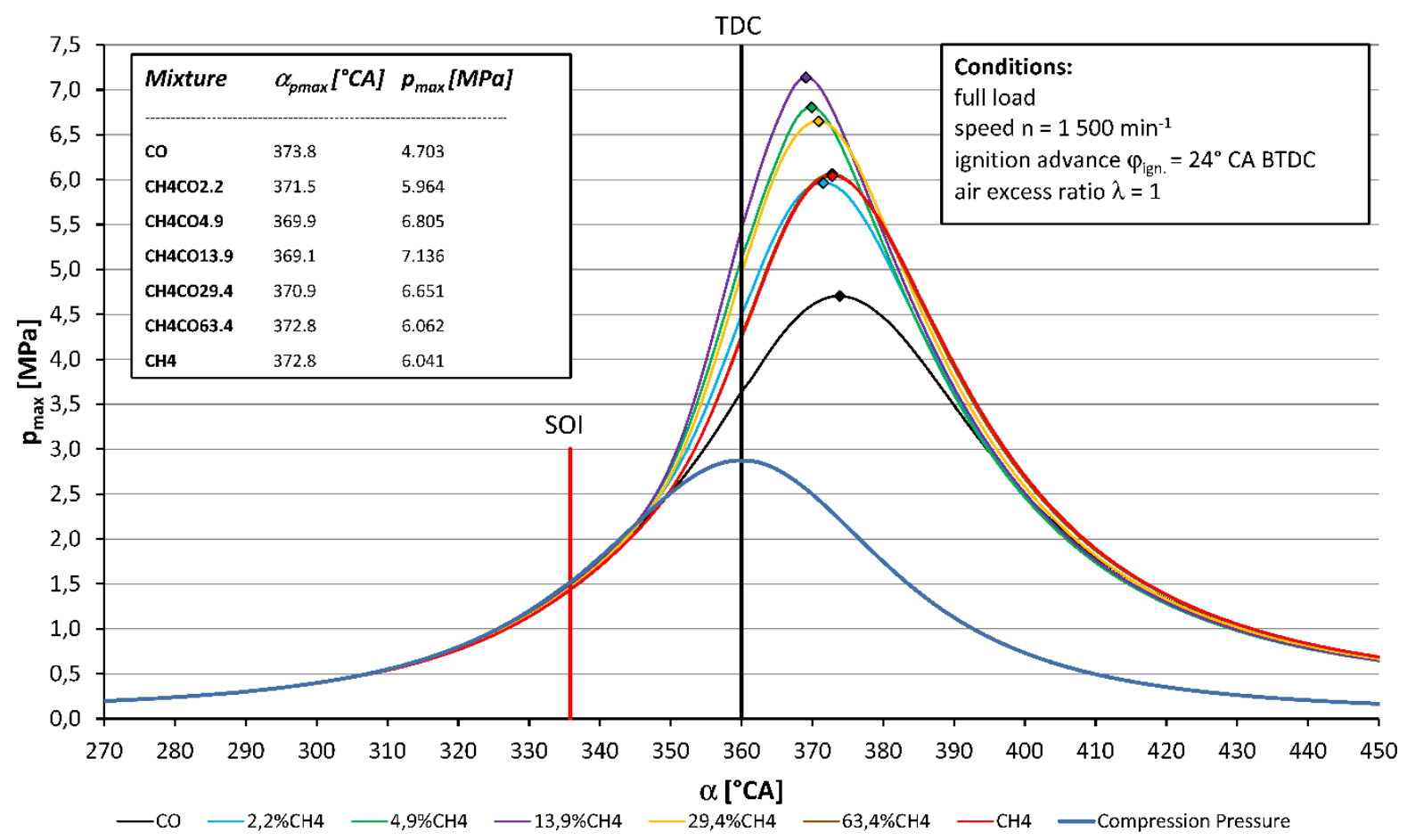

Fig. 4 Traces of pressure for various $\mathrm{CO}$ and $\mathrm{CH}_{4}$ mixtures between 270 and $450^{\circ} \mathrm{CA}$

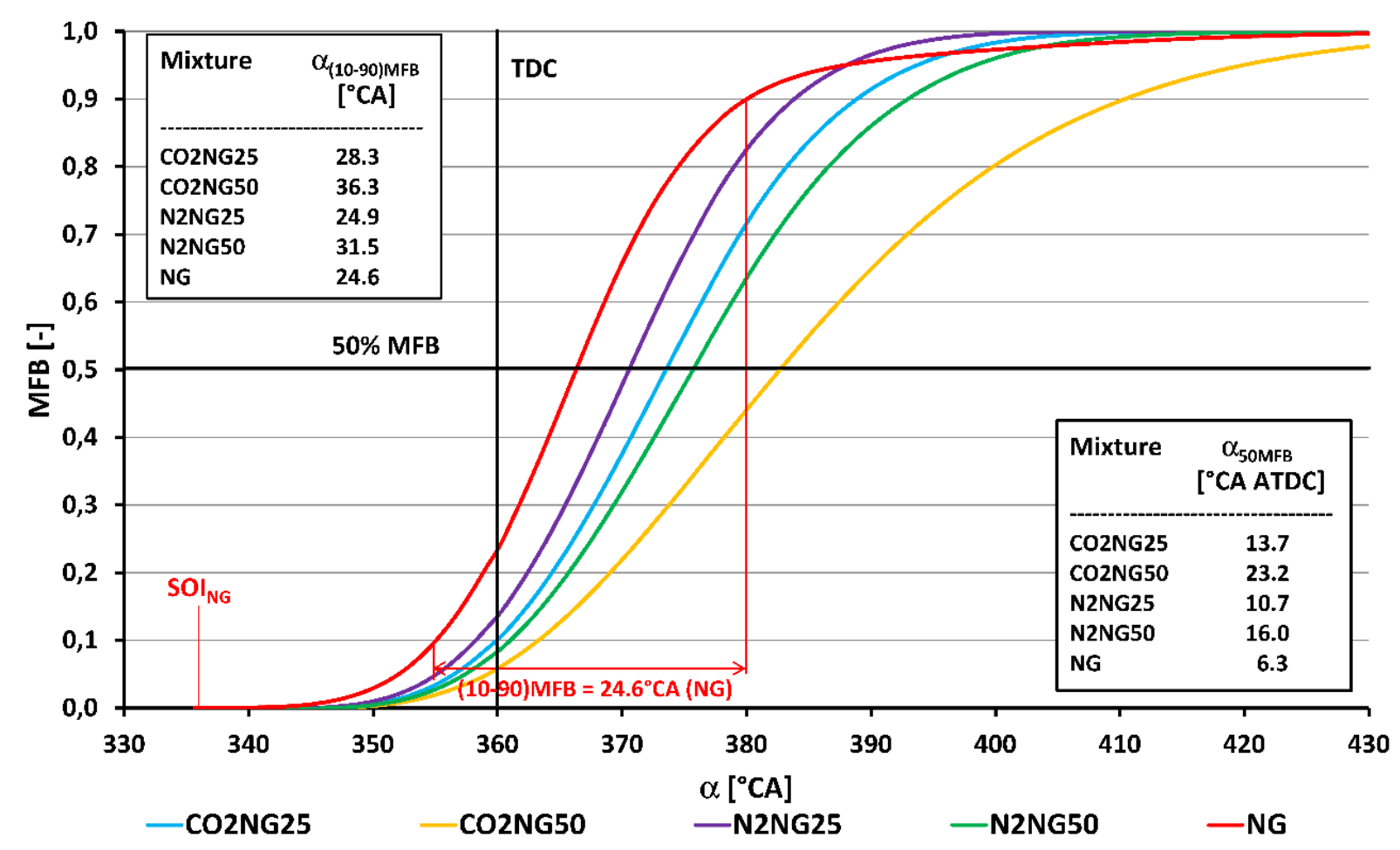

Fig. 5 Course of in-cylinder heat release for natural gas and inert gases

With a change of mixture of combustibles to a mixture of natural gas and inert gas, the burning duration generally prolonged compared to those of methane and carbon monoxide. As mentioned above, the reference of methane was considered equal with natural gas, as it 
contained $98 \%$ methane at the time of measurement. This was also confirmed by the duration of combustion phase which was only $0.1^{\circ} \mathrm{CA}$ shorter than for $\mathrm{CH}_{4}$. Peak pressures varied by only $0.012 \mathrm{MPa}$ and were shifted by $0.7^{\circ} \mathrm{CA}$ as can be seen from Figure 6 . The main combustion phase was the shortest for mixture of $25 \% \mathrm{~N}_{2}$ with a value of $24.9^{\circ} \mathrm{CA}$. With the same amount of carbon dioxide, the phase prolonged by $3.4^{\circ} \mathrm{CA}$ to $28.3^{\circ} \mathrm{CA}$. Mixtures that contained $50 \%$ of either of the inert gases, the phase was $31.5^{\circ} \mathrm{CA}$ for $\mathrm{N}_{2}$ and $36.3^{\circ} \mathrm{CA}$ for $\mathrm{CO}_{2}$. The point of $50 \%$ MFB of mixtures moved between $23.2^{\circ} \mathrm{CA}$ and $10.7^{\circ} \mathrm{CA}$ ATDC. Pure natural gas had a value of $8.7^{\circ} \mathrm{CA}$ ATDC as can be seen from Figure 5. It can be assumed from the results that the excess of nitrogen is a more favourable candidate than carbon dioxide due to a higher burning velocity.

As the inert gases are not reactive, less heat is added to the cycle and the peak pressure are also marginally lower than those of pure natural gas. The effect of addition of inert gas also caused the shift of the point of maximum pressure but in the opposite direction. This was accounted to the smaller and slower net heat release and pressure rise which was dominated by the pressure drop from gas expansion. The peak pressure for pure natural gas was $6.029 \mathrm{MPa}$ at the $373.5^{\circ} \mathrm{CA}$. By mixing $25 \%$ of carbon monoxide to the natural gas, the peak pressure moved by $2.1^{\circ} \mathrm{CA}$ to $375.6^{\circ} \mathrm{CA}$ with a value of $4.651 \mathrm{MPa}$. In case of nitrogen the shift was only $-0.3^{\circ} \mathrm{CA}$ and reached a value of $5.461 \mathrm{MPa}$. The values of peak pressure for these mixtures were $4.65 \mathrm{MPa}$ for $\mathrm{CO}_{2}$ and $5.461 \mathrm{MPa}$ for $\mathrm{N}_{2}$ respectively. The mixtures of $50 \%$ inert gas caused the shift of the peak pressure point towards TDC as mentioned above. In case of 50\% $\mathrm{CO}_{2}$, the peak pressure reaches value of $2.98 \mathrm{MPa}$ at the point of $369.6^{\circ} \mathrm{CA}$, half of pure natural gas. The declined of peak pressure for $50 \% \mathrm{~N}_{2}$ was not so high as with the $\mathrm{CO}_{2}$. For such mixture, it occurred at $374.2^{\circ} \mathrm{CA}$. The pressure at this point was $4.467 \mathrm{MPa}$ as can be seen from the following Fig. 6.

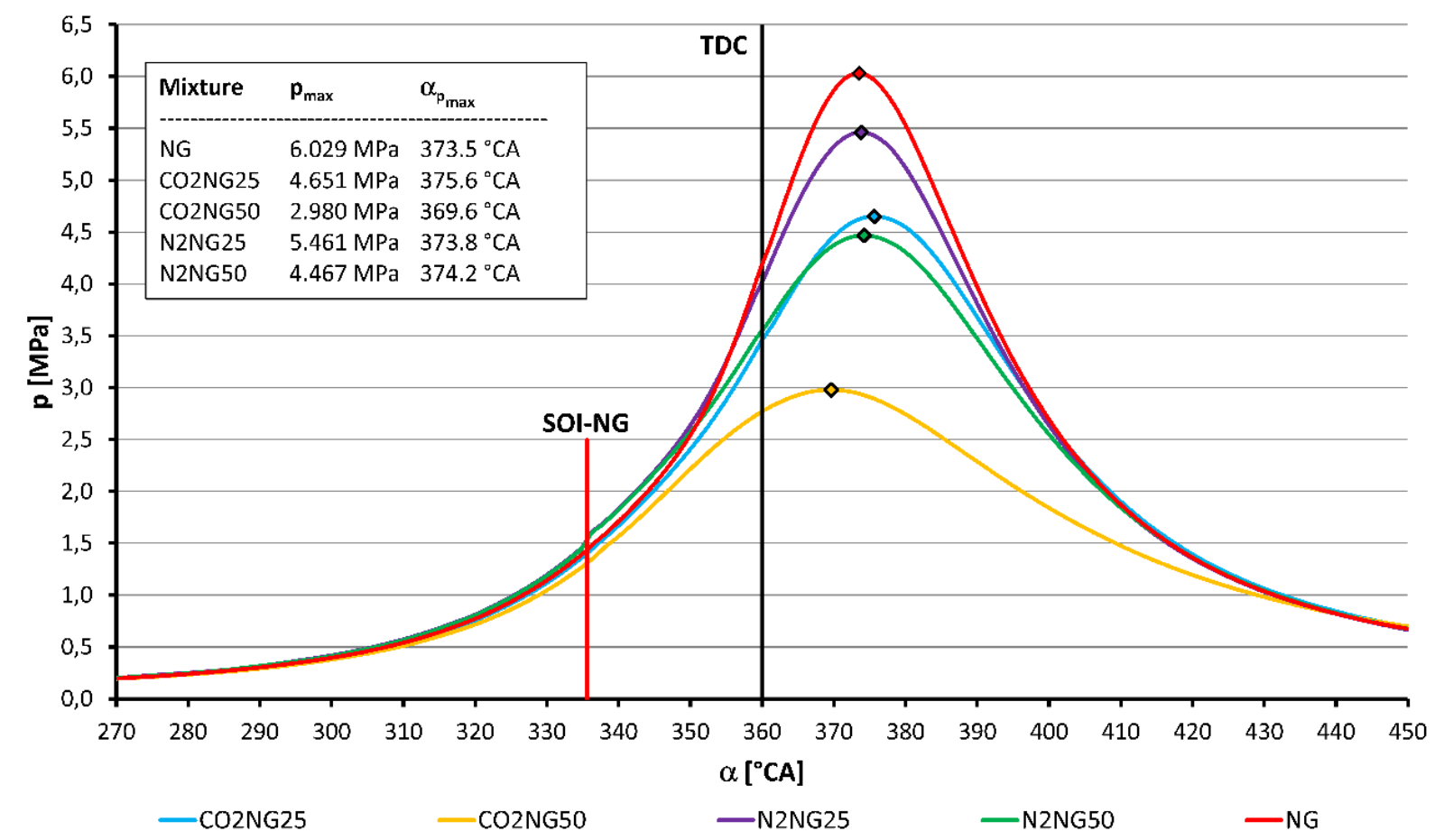

Fig. 6 Traces of pressure for mixtures of natural gas and inert gases between 270 and $450^{\circ} \mathrm{CA}$ 


\section{CONCLUSION}

By analyzing various mixtures at $1500 \mathrm{~min}^{-1}$ of methane with carbon monoxide and natural gas with inert gases, the following can be concluded:

- Indicated mean effective pressre increases by around $5.5 \%$ for $\mathrm{CH}_{4}$ compared to $\mathrm{CO}$

- $\quad$ By mixing 5 to $15 \%$ of $\mathrm{CO}$ to $\mathrm{CH}_{4}$ the overall burning velocity and pressure rise rate increases $\left(0.326 \mathrm{MPa} /{ }^{\circ} \mathrm{CA}\right)$. This can also can be seen from maximum pressure in the cylinder (7.1 MPa)

- $\quad$ The volumetric heating value of the stoichiometric mixture gets lower with the growing share of $\mathrm{CH}_{4}\left(3476 \mathrm{~kJ} . \mathrm{m}^{-3}\right.$ for $\mathrm{CO}$ and $\left.3185 \mathrm{~kJ} . \mathrm{m}^{-3}\right)$

- $\quad$ Greater pressure rise rate can be achieved by addition of $\mathrm{CH}_{4}$ to the mixture $(0.139$ $\mathrm{MPa} /{ }^{\circ} \mathrm{CA}$ for $\mathrm{CO}$ and $0.191 \mathrm{MPa} /{ }^{\circ} \mathrm{CA}$ for $\mathrm{CH}_{4}$ )

- $\quad$ By introducing any carbon dioxide or nitrogen to the mixture, the maximum pressure decreases (by $50 \%$ for $50 \%$ of $\mathrm{CO}_{2}$ and $30 \%$ for $\mathrm{N}_{2}$ )

- $\quad$ Addition of carbon dioxide or nitrogen extends all combustion phases

- $\quad$ The combustion duration for $\mathrm{N}_{2}$ are smaller and peak pressures are higher and closer to TDC compared to addition of same amount of $\mathrm{CO} 2$. Therefore, the combustion with $\mathrm{N}_{2}$ is more favourable than with $\mathrm{CO}_{2}$.

\section{ACKNOWLEDGEMENT}

This work was supported by the Slovak Research and Development Agency under Contract No. APVV-17-0006, APVV-18-0023, APVV-20-0046 and was also supported by the Slovak Scientific Grant Agency under the Contracts No. VEGA 1/0301/17, and Cultural and Educational Grant Agency KEGA 026STU-4/2018 and KEGA 041STU-4/2020.

\section{REFERENCES}

[1] Begum, S., Rasul, M. G., Cork, D., Akbar, D. “An experimental investigation of solid waste gasification using a large pilot scale waste to energyplant", Procedia Engineering, 90, pp. 718 - 724, 2014. DOI: 10.1016/j.proeng.2014.11.802

[2] Belgiorno, V., de Feo, G., della Rocca, C., Napoli, R. M. A. "Energy from gasification of solid wastes", Waste Management 23 (1), pp. 1 - 15, 2003. DOI: 10.1016/S0956053X(02)00149-6

[3] Asadullah, M. "Biomass gasification gas cleaning for downstream applications: A comparative critical review", In Renewable and Sustainable Energy Reviews 40, pp. 118 -132, 2014. DOI: 10.1016/j.rser.2014.07.132

[4] Molino, A., Chianese, S., Musmarra, D. "Biomass gasification technology: The state of the art overview", Journal of Energy Chemistry 25 (1), pp. 10 - 25, 2016. DOI: 10.1016/j.jechem.2015.11.005

[5] Thapa, S., Bhoi, P. R., Kumar, A., Huhnke, R. L. "Effects of syngas cooling and biomass filter medium on tar removal”, Energies 10 (3), 2017. DOI: 10.3390/en10030349

[6] de Filippis, P., Scarsella, M., de Caprariis, B., Uccellari, R. "Biomass Gasification Plant and Syngas Clean-up System”, Energy Procedia 75, pp. 240 - 245, 2015. DOI: 10.1016/j.egypro.2015.07.318

[7] Milata, M., Musil, M. "Reduction of Crankshaft Stress by Using of the Torsional Vibration Damper", Strojnícky časopis - Journal of Mechanical Engineering 70 (2), pp. 117-132, 2020. DOI: $10.2478 /$ scjme-2020-0025 
[8] Prasad, K. Hari, Srinivasan, C. Ananda, Kumar, K. Praveen "Pefformance and Emission Evaluation of Direct Inejction Diesel Engine Using Canola, Sesame Biodiesels with NButanol", Strojnícky časopis - Journal of Mechanical Engineering 71 (1), pp. 139 - 148, 2021. DOI: $10.2478 /$ scjme-2021-0012

[9] Kapilan, N., Jullya, N. "Studies on improvement of performance of compression ignition engine fuelled with mixture of honge biodiesel and tire pyrolysis oil", Strojnícky časopis - Journal of Mechanical Engineering 68 (1), pp. 15 - 24, 2018. DOI: 10.2478/scjme2018-0002 